\title{
A Comparison of Herpes Simplex Virus Specific Antibodies Found in Human Milk and Serum
}

\author{
ANNETTE LIU, LISA SANCHEZ-PESCADOR, GUILLERMO RUIZ-PALACIOS, \\ ARDYTHE L. MORROW, LARRY K. PICKERING, AND STEVE KOHL \\ Department of Pediatrics, University of California, San Francisco and San Francisco General Hospital, San \\ Francisco, CA 94110; Department of Infectious Diseases, Instituto Nacional de la Nutricion, Mexico City. \\ Mexico; and Department of Pediatrics, University of Texas Medical School, Houston, Texas 77030
}

\begin{abstract}
It is not known if milk antibody protects infants from herpes simplex virus (HSV) infection. As a first step to test this hypothesis, anti-HSV antibodies were studied in human milk. Paired serum and milk samples were analyzed for anti-HSV antibodies by ELISA, Western blot analysis (WBA), neutralization (NT) plaque assay, and antibody-dependent cellular cytotoxicity (ADCC) assay. Nineteen of the 20 serum samples showed anti-HSV activity by ELISA and ADCC, and 18 showed activity by WBA and NT. We found a significant association between the immunoassays for detection of anti-HSV antibodies in sera. Fewer of the human milk samples showed anti-HSV activity; only one milk sample was positive by ELISA and one by NT assay, four by ADCC and 12 by WBA. The milk sample from the seronegative donor was also negative. We found a poor association of antibody titers in human milk and serum antibody titers using ELISA, NT, and ADCC assays. There was a significant $(p=0.022)$ association between serum and milk results using WBA. Among the four assays, WBA was the most sensitive for antibody detection. It will be used in an on-going prospective study to determine the role of anti-HSV antibody in the protection against $\mathrm{HSV}$ infections in infants. (Pediatr Res 31: $591-595,1992$ )
\end{abstract}

\section{Abbreviations}

HSV, herpes simplex virus

WBA, Western blot analysis

NT, neutralization

ADCC, antibody-dependent cellular cytotoxicity

Neonatal HSV infection occurs in approximately 1 of every 2000 to 5000 births per year, and the incidence is still on the rise (1). Without treatment, many of these infections can result in encephalitis, disseminated disease, or even death. There are conflicting studies on the ability of maternal antibody, acquired passively through the placenta, to amelioriate human neonatal HSV infection. Several studies indicate that infants with high levels of transplacentally derived type-specific or functional antibody fare better than those with low levels (2-4).

Animal experiments have unequivocally shown that a high concentration of passively acquired antibody can protect against low challenge doses of HSV. Studies in newborn mice demonstrated that passive transfer of serum antibodies obtained from

Received November 12, 1991; accepted February 6, 1992.

Correspondence: Steve Kohl. M.D., Department of Pediatrics, Division of Pediatric Infectious Diseases, University of California, San Francisco at San Francisco General Hospital, 1001 Potrero Avenue, 6E3, San Francisco, CA 94110.

Supported by NIH Grant HD 13021. mice, rabbits, or humans protected against viral challenge using HSV - 1 or HSV-2 $(5-10)$. Acquired protective humoral immunity in neonatal mice has been reported to be derived from the maternal milk $(11,12)$. In mice, unlike humans, milk antibody is absorbed through the gastrointestinal tract.

Human milk has been shown to contain nonspecific and specific antiviral properties (13-18). Milk lipids, metabolized into fatty acids and monoglycerides in the infant's stomach by gastric and lingual lipases, have been demonstrated to disrupt HSV and other enveloped viruses, such as measles virus and vesicular stomatitis virus $(19,20)$. A nonspecific factor in the aqueous phase of milk has also been reported as having antiviral activity by interfering with virus entry $(21)$. This heat-stable nonIg macromolecule was shown to have weak neutralizing activity against HSV-2 (22). Leukocytes in milk comprised primarily of macrophages and neutrophils have been known to phagocytize foreign matter in vitro $(15,23)$. They are capable of producing interferon- $\alpha$ after viral stimulation (24) and killing viral infected cells by an ADCC mechanism (25).

Secretory $\operatorname{IgA}$, a specific humoral factor in milk, is thought to prevent replication of pathogens in vivo (18). Studies in humans have linked protection against cholera (26), Escherichia coli toxin-mediated enteritis (27), Campylobacter diarrhea (28), and neonatal rotavirus infection $(29,30)$ with secretory IgA in milk. A study of the inhibitory effect of human colostrum and milk on oral poliovirus vaccination indicated that secretory $\operatorname{IgA}$ from colostrum prevented seroconversion of breast-fed infants (31).

There is little data regarding the various types of anti-HSV antibodies in human milk. Although the role of human milk in protection against HSV infection in infants is unknown, we hypothesize that human milk antibody may offer some protection against HSV infection. The first step in approaching this hypothesis was to characterize the presence and type of anti-HSV antibody in human milk. The purpose of this study thus was to compare HSV-specific antibody levels in matched maternal sera and milk samples by ELISA, NT assay, WBA, and ADCC assay.

\section{MATERIALS AND METHODS}

Serum and milk samples. The clinical samples were obtained from women in Mexico City during a longitudinal prospective study of the role of human milk regarding protection of infants against acquisition of infectious diseases. Matched maternal serum and milk samples were collected from women ranging from 49 to $158 \mathrm{~d}$ postpartum. The milk samples were collected with a breast pump (Egnell, Cary, IL) (28). The samples were stored and transported frozen at $-20^{\circ} \mathrm{C}$. In our laboratory, serum samples were heat inactivated at $56^{\circ} \mathrm{C}$ for $30 \mathrm{~min}$ and stored in small aliquots at $-20^{\circ} \mathrm{C}$ until use. Milk samples were separated into aqueous and lipid fractions by centrifugation at $300 \times g$ for $20 \mathrm{~min}$ and were stored at $-20^{\circ} \mathrm{C}$. Aqueous portions were used in all immunoassays. Known HSV-positive and HSV-negative 
sera were included as controls in all immunoassays. All samples were obtained after informed consent with approval from the Institutional Review Boards of the University of Texas Medical School, Houston, and the Institute of Nutrition, Mexico City.

Antigen preparation. The antigen used for ELISA and WBA consisted of a detergent-solubilized infected-cell lysate. It was prepared by infecting Vero cells with HSV-1 (HE strain) at a multiplicity of infection of 10 . After $30 \mathrm{~h}$ of incubation, $100 \%$ cytopathic effect was observed in the viral flasks. The cells were scraped, pelleted, and washed with PBS containing $0.9 \mathrm{mM} \mathrm{CaCl}_{2}$ and $0.5 \mathrm{mM} \mathrm{MgCl}_{2}$. The cells were disrupted in TNEN buffer (0.02 M Tris-HCl, $\mathrm{pH} 8.0,0.1 \mathrm{M}$ sodium chloride, $1 \mathrm{mM}$ EDTA, $0.5 \%$ nonidet P. 40 , and $0.5 \%$ sodium deoxycholate) to which protease inhibitors had been added $(0.24$ trysin inhibitory units/ $\mathrm{mL}$ aprotinin and $1 \mathrm{mM}$ phenylmethylsulfonyl fluoride, Sigma Chemical Co., St. Louis, MO). $\mathrm{CaCl}_{2}$ was added to a concentration of $5 \mathrm{mM}$, and the mixture was rocked for $30 \mathrm{~min}$ at $4^{\circ} \mathrm{C}$. The solution was clarified by centrifugation and stored at $-70^{\circ} \mathrm{C}$ in small aliquots. Mock-infected Vero cell lysate, identically prepared, was used as the control antigen. The protein concentrations were determined using the Bio-Rad protein assay (BioRad Laboratories, Richmond, CA), and the viral and mockinfected samples were diluted to $1.8 \mathrm{mg} / \mathrm{mL}$ in TNEN, aliquoted, and stored at $-70^{\circ} \mathrm{C}$.

ELISA. Maternal serum and milk samples were measured in a direct ELISA to determine the level of HSV-specific antibodies. Infected or mock cell lysate diluted to $20 \mu \mathrm{g} / \mathrm{mL}$ in PBS (in 96well plates; Becton Dickinson, Oxnard, CA) was used as a source of antigen. Serum and milk sample dilutions were incubated with peroxidase-conjugated goat anti-human $\mathrm{IgG}$ (for sera) or goat anti-human secretory IgA (for milk) (Sigma Chemical Co.). Dilution and wash buffer consisted of PBS containing $1 \%$ goat serum and $0.3 \%$ Tween 20 for sera or TNM buffer $(50 \mathrm{mM}$ Tris$\mathrm{HCl}, \mathrm{pH} 7.5$, with $200 \mathrm{mM} \mathrm{NaCl}$ and $2 \%$ nonfat dry milk) (Lucerne, Oakland, CA) for milk samples. Wells were subsequently developed by the addition of substrate buffer containing $o$-phenylenediamine dihydrochloride. The reciprocal of the sera or milk dilution corresponding to $50 \%$ of the peak of the positive control sample signal was considered as the titer. A control experiment using a negative milk sample mixed with a positive serum $(1: 1)$ sample was performed identically to ensure that the conjugate was capable of detecting anti-HSV IgA antibody in milk.

Electrophoresis and WBA. Pre-made 7.5\% SDS-PAGE gels (Bio-Rad Laboratories) were used for electrophoresis. The viral and mock antigen samples were prepared as described above and boiled for $3 \mathrm{~min}$ in laemmli sample buffer. Fifty $\mu \mathrm{g}$ protein was loaded in each lane. High molecular weight markers were run as standard controls (Bethesda Research Laboratories, Gaithersburg, MD). The samples were electrophoresed at $90 \mathrm{~V}$ for 90 min. Antigens were transferred to nitrocellulose paper using a Hoefer mini-transphor unit (Hoefer Scientific Instruments, San Francisco, CA). Transfer was carried out for $45 \mathrm{~min}$ at $75 \mathrm{~V}$. After soaking in TNM for $30 \mathrm{~min}$, the nitrocellulose paper was cut into strips corresponding to the well lanes and incubated at $4^{\circ} \mathrm{C}$ overnight with $1 / 100$ dilution of sera in TNM, or $1 / 4$ dilution of human milk in TNM containing $10 \%$ background reduction buffer (Calypte Biomedical, Berkeley, CA). The following day, the strips were subjected to three 10 -min washes in TNM and incubated in a $1 / 500$ dilution of peroxidase-conjugated goat anti-human IgG (serum blots) or at a 1/200 dilution of goat anti-human secretory IgA (milk blots) (Sigma Chemical Co.) for $1 \mathrm{~h}$ at room temperature. Excess conjugate was removed with three consecutive washes with PBS containing $0.1 \%$ Triton $\mathrm{X}-100$. The strips were developed for $10 \mathrm{~min}$ using $1.0 \mathrm{mg} / \mathrm{mL}$ chloro-1-naphthol dissolved in cold methanol, $10 \mathrm{mM}$ Tris- $\mathrm{HCl}$, $\mathrm{pH} 7.5,50 \mathrm{mM} \mathrm{NaCl}$, and $0.016 \%$ hydrogen peroxide. The resulting Western blots were dried and photographed. The blots were rated,+++ , or +++ according to the intensity of the bands, with + representing weak, ++ as medium intensity, and
+++ as dark bands. To identify specific viral protein bands on the human serum and milk sample blots, murine MAb, which recognized various glycoproteins including $\mathrm{gB}, \mathrm{gD}$, and $\mathrm{gE}$ [provided by Drs. Lenore Pereira (University of California, San Francisco) and Harvery Friedman (University of Pennsylvania)] were reacted with the viral antigen blots. MAb binding was detected with peroxidase-conjugated goat anti-mouse IgG followed by development. In addition, a control experiment that used a positive serum sample mixed with a negative milk sample at a $1 / 10$ dilution as the primary antibody mixture was done to confirm that it was possible to detect HSV-specific IgA by Western blot in the presence of milk.

NT assay. NT assays were performed by incubating serial dilutions of serum or milk with approximately 50 plaque forming units of HSV-1 (HE strain) for $1 \mathrm{~h}$ at $37^{\circ} \mathrm{C}$. This mixture was adsorbed on Vero cell monolayers in duplicate using six-well plates, for $1 \mathrm{~h}$ at $37^{\circ} \mathrm{C}$. The inoculum was removed and the cells were overlayed with media containing $0.5 \%$ agarose. After a 3-d incubation at $37^{\circ} \mathrm{C}$, the agarose overlay was removed, and monolayers were stained. The reciprocal of the dilution of serum or milk that resulted in a $50 \%$ or greater reduction of plaques was reported as the NT titer.

$A D C C$ assay. Microcytotoxicity assays were performed as previously described $(3,5)$. Chang liver cells infected with HSV1 and labeled with radioactive sodium chromate were used in an 18-h ADCC assay. Effector cells were mononuclear leukocytes isolated from heparinized human peripheral blood used at an effector to target ratio of 50:1. Serial dilutions of the serum or milk samples starting at $1 / 20$ were added to the appropriate wells, resulting in a final volume of $200 \mu \mathrm{L}$. A control experiment using a negative milk sample mixed with an equal volume of a seropositive serum sample was also performed to ensure efficient detection of serum ADCC activity in the presence of milk. Percentage of ADCC was calculated by [ $\% \mathrm{Cr}$ release of target cells + effector cells + test sample $)-(\% \mathrm{Cr}$ release of target cells + effector cells + nonimmune sera $)] \div[100-(\% \mathrm{Cr}$ release of target cells + effector cells + nonimmune sera) $] \times 100$. The reciprocal of the last dilution of sera or milk resulting in ADCC greater than $10 \%$ was considered as the ADCC titer. This assay detects antibodies to HSV type 1 and 2 (3). All effector cell blood samples were obtained after informed consent with approval by the institutional review board of the University of San Francisco, San Francisco, CA.

Statistical evaluation. Comparisons were performed using $\chi^{2}$ analysis and correlation analysis.

\section{RESULTS}

A summary of ELISA titers, WBA results, NT titers, and ADCC titers is given in Table 1. Anti-IgA conjugate was used for milk ELISA and WBA, whereas anti-IgG conjugate was used for sera ELISA and WBA. The samples are arranged in order of descending ELISA titers. One woman (no. 20) did not show activity against HSV in her serum or milk in any of the assays and was classified as seronegative regarding HSV. Subject 19 was weakly seropositive. Low ELISA and ADCC titers were obtained (30 and 320, respectively), but her serum was nonneutralizing and gave no reaction by WBA. The sera of the remaining 18 women had positive anti-HSV activity with ELISA titers ranging from 530 to 3460 , NT titers between 80 and 1280 , ADCC titers from 1280 to 20480 , and multiple strong bands on Western blots. When comparing results of assays of serum samples, there was a $100 \%$ concordance between WBA and NT and 95\% concordance among all four assays. When $\log$ values were compared, correlations ranged from 0.76 to 0.90 , indicating that all possible pair correlations were significantly correlated. The correlations became poor when serum specimens from the two mothers that gave negative or low values were excluded. In summary, all assays agree in dichotomizing absent versus present 
Table 1. Anti-HSV antibody in human serum and milk

\begin{tabular}{|c|c|c|c|c|c|c|c|c|}
\hline \multirow[b]{2}{*}{ Women } & \multicolumn{4}{|c|}{ Sera* } & \multicolumn{4}{|c|}{ Milk* } \\
\hline & ELISA & WBA & NT & $\mathrm{ADCC}$ & ELISA & WBA & $\mathrm{NT}$ & $\mathrm{ADCC}$ \\
\hline 1 & 3460 & +++ & 640 & 24080 & 15 & +++ & $<10$ & 320 \\
\hline 2 & 2580 & +++ & 160 & 5120 & $<5$ & ++ & $<10$ & $<20$ \\
\hline 3 & 2300 & +++ & 640 & 5120 & $<5$ & - & $<10$ & $<20$ \\
\hline 4 & 2300 & ++ & 320 & 5120 & $<5$ & - & $<10$ & $<20$ \\
\hline 5 & 2090 & +++ & 640 & 20480 & $<5$ & ++ & $<10$ & $<20$ \\
\hline 6 & 1810 & +++ & 160 & 5120 & $<5$ & +++ & $<10$ & $<20$ \\
\hline 7 & 1710 & +++ & 320 & 20480 & $<5$ & + & $<10$ & 20 \\
\hline 8 & 1710 & +++ & 160 & 1280 & $<5$ & - & $<10$ & $<20$ \\
\hline 9 & 1540 & ++ & 1280 & 5120 & $<5$ & - & $<10$ & 20 \\
\hline 10 & 1400 & +++ & 320 & 20480 & $<5$ & + & $<10$ & $<20$ \\
\hline 11 & 1330 & +++ & 160 & 5120 & $<5$ & ++ & $<10$ & $<20$ \\
\hline 12 & 1210 & ++ & 320 & 1280 & $<5$ & - & $<10$ & $<20$ \\
\hline 13 & 1210 & +++ & 160 & 1280 & $<5$ & - & $<10$ & $<20$ \\
\hline 14 & 1190 & +++ & 160 & 5120 & $<5$ & + & $<10$ & 20 \\
\hline 15 & 850 & +++ & 1280 & 5120 & $<5$ & ++ & $<10$ & $<20$ \\
\hline 16 & 625 & +++ & 160 & 5120 & $<5$ & +++ & $<10$ & $<20$ \\
\hline 17 & 625 & +++ & 80 & 5120 & $<5$ & ++ & $<10$ & $<20$ \\
\hline 18 & 530 & +++ & 80 & 5120 & $<5$ & + & 80 & $<20$ \\
\hline 19 & 30 & - & $<10$ & 320 & $<5$ & - & $<10$ & $<20$ \\
\hline 20 & $<5$ & - & $<10$ & $<20$ & $<5$ & - & $<10$ & $<20$ \\
\hline
\end{tabular}

* Results were reported as reciprocal of the last positive dilution except for Western blots, which were rated according to the intensity of the bands with + representing faint, ++ as medium intensity, and +++ as dark bands. - , No visible bands.

serum antibody but have a poor correlation regarding quantity of antibody.

Milk from the 18 seropositive women demonstrated relatively few positive results. Only one sample (subject 1) showed significant anti-HSV activity by ELISA with a titer of 15 . It also had the highest ADCC titer, 320, and was positive by WBA. All other milk samples were negative by ELISA. Similarly, only one milk sample (subject 18) had activity in the NT assay, with a titer of 80. It was also positive by WBA (+), but was ELISA and ADCC negative. Most of the milk samples did not mediate ADCC, with only four samples being positive. As noted, subject 1 had an ADCC titer of 320, and subjects 7, 9, and 14 had titers of 20 .

Although there were relatively few positive milk results in the ELISA, NT, and ADCC assays, 12 of the 20 milk samples showed reactions with a variety of virus-specific proteins by WBA. The eight negative Western blots included sample 20, which came from an HSV seronegative donor, sample 19 from a weak HSV seropositive donor, and samples $3,4,8,9,12$, and 13 from seropositive donors. This indicated a poor agreement between results from the NT, ADCC, and ELISA in the milk system. Nevertheless, there was a significant $(p=0.022)$ correlation between serum $\operatorname{IgG}$ and milk IgA anti-HSV antibody detected by WBA. Mothers with serum antibody titers of $3+$ were significantly $(p=0.002)$ more likely to have positive milk samples.

The pattern of bands on the $\mathrm{IgG}$ serum blots was not reflective of the IgA milk blots on a sample per sample basis. In general, the serum blots showed many more viral specific bands than the milk blots. There was no reaction of the sera with proteins found in the mock antigen, but several of the milk samples reacted slightly with mock antigen. At least one to two dozen HSVspecific bands appeared with all positive serum samples. The multitude of bands on the serum blots made it difficult to determine the identity of individual bands. In some cases, bands were too close to be clearly resolved. Murine MAb to glycoprotein $\mathrm{B}, \mathrm{D}$, and $\mathrm{E}$ were used as a source of specific antibody in an attempt to identify some of the viral bands. Three of the serum samples (nos. 2, 7, and 18) appeared to react with a band that migrated between 220 and $230 \mathrm{kD}$, and three sera (samples 6 , 10 , and 18 ) reacted to a protein of about $130 \mathrm{kD}$, which probably corresponds to glycoprotein C. Many of the serum samples reacted with bands between 100 and $120 \mathrm{kD}$ (samples $1-6,8-$ $13,15,17$, and 18); glycoprotein B migrates in this region. The sera also reacted with a large number of bands ranging from 25 to $83 \mathrm{kD}$, where glycoproteins $\mathrm{D}(59 \mathrm{kD})$ and $\mathrm{E}(70 \mathrm{kD})$ are found. The 12 positive milk samples seemed to fall into three main groups: those that reacted with at least a dozen viral proteins over a large range of molecular weights (samples 2, 57,11 , and 15), those that reacted rather strongly with only one or two proteins (samples 1 and 16), and those that reacted predominantly to proteins with the lower molecular weights, between 30 and $45 \mathrm{kD}$ (samples 10 and 14).

Because we were unable to detect anti-HSV activity in many of the milk samples, antibody addition experiments were performed to check the ability of the ELISA, WBA, and ADCC assay to detect anti-HSV antibody in milk. In each case, serum from an HSV antibody-positive donor was mixed with a milk sample that was obtained from a seronegative donor (see Materials and Methods for details of mixing experiments). In the ELISA assay, the mixed sample using this anti-IgA conjugate resulted in a titer of 29 and the positive serum had an anti-IgA HSV titer of 18 when tested alone. By WBA using an anti-IgA conjugate, identical patterns of bands were observed with the mixed sample and positive serum. Identical titers of 1280 were obtained in the ADCC assay when the mixed sample was compared with the positive serum alone. These experiments confirmed that the ELISA, WBA, and ADCC would have detected anti-HSV IgA antibody in milk had there been a sufficient amount present and that our negative milk results were not due to a nonspecific inhibitory effect of milk.

\section{DISCUSSION}

There is a dearth of information regarding functional antiHSV antibody in human milk. This is the first study to use four immunoassays, ELISA, WBA, NT, and ADCC to compare HSVspecific antibody activity in maternal sera to activity in milk. Our results indicated a close agreement among the immunoassays for the measurement of HSV-specific antibody in human sera. Similar results for the detection of HSV antibody in serum specimens by these four assays have been reported (32-35). However, our results demonstrated less agreement between the immunoassays in the milk system. Few milk samples had detectable anti-HSV activity, and the samples with activity had titers that were considerably lower than the serum samples. Similar discrepancies have been reported by Lopez et al. (22) for detection of anti-HSV antibodies in milk by ELISA and NT assay.

Human milk is a complex mixture of protein, carbohydrates, and lipids and has been shown to have inhibitory effects in several immunoassays. To prove that the immunoassays were capable of detecting HSV-specific IgA antibody in the milk, experiments using negative milk mixed with serum from HSVpositive donors were performed. The positive results confirmed that the ELISA, WBA, and ADCC assays were capable of detecting anti-HSV antibody in human milk and that the aqueous fraction of milk does not appear to contain inhibitory factors that interfere with antibody detection in these assays. Although colostrum has been shown to inhibit ADCC effector cell function (25), the negative ADCC milk titers were not due to this effect. Low or absent milk ADCC titers were not surprising because ADCC to HSV-infected cells has been shown to be mediated by IgG and not $\lg \mathrm{A}$, which is the predominant milk antibody (36). The negative NT and ELISA results could be explained by the milk samples being obtained 49 to $158 \mathrm{~d}$ postpartum and thus having antibody levels that were too low to be detected by these assays. It has been previously shown that milk antibody levels diminish with time from birth (37). Furthermore, the immediate freezing of samples should have prevented the generation of nonantibody-mediating neutralizing substances, such as fatty acids, and thereby decreased nonspecific neutralization (19). 
Most of the milk Western blots showed a positive signal, although many of the milk samples were negative by ELISA, NT, and ADCC assays. One explanation for this discrepancy is the different levels of sensitivity of the immunoassays, especially for detection of IgA. The large amount of viral antigen, the high concentration of milk, and the overnight incubation step could have made the WBA more sensitive than the ADCC, ELISA, and NT assays. Although WBA is not a functional assay, its increased sensitivity suggests its utility to detect milk antibody to HSV antigens.

The clinical significance of these results has yet to be determined. Breast-feeding has been associated with protection against gastrointestinal tract infections (enteromammary axis of immunity) (38), such as those caused by $E$. coli, Vibrio cholerae, Campylobacter, and Shigella $(26,28,39-41)$. Protection against respiratory tract infections (bronchomammary axis) is less definite. However, studies do exist that show that breast-feeding protects against upper respiratory tract infections, including those associated with Haemophilus influenzae $(42-45)$, otitis media (46), and lower respiratory tract infections (47). Although protection has been demonstrated, most of these studies do not link this protection to a specific component in milk. High anti-HSV ADCC antibody titers in maternal and neonatal sera have been linked to protection against the disseminated form of neonatal HSV (3). Studies evaluating colostral leukocytes have shown them to mediate ADCC in vitro (24), but inasmuch as ADCC antibody was not present in this study, their role in vivo in this situation is questionable. Five studies have identified secretory IgA in human milk as the protective agent in the prevention of illness (26-30). However, the possible role of anti-HSV IgA milk antibodies as detailed by WBA in protection against HSV infection is currently unknown. An ongoing prospective study by our group of HSV infection in breast-fed infants should provide further information regarding the role of breast-feeding and the specific role of HSV antibody in prevention or amelioration of this disease.

\section{REFERENCES}

1. Whitley RJ 1990 Herpes simplex virus infections. In: Remington JS, Klein JO (eds) Infectious Diseases of the Fetus and Newborn Infant. WB Saunders, Philadelphia, pp 282-305

2. Yeager AS, Arvin AM, Urbani LJ, Kemp JA 1980 Relationship of antibody to outcome in neonatal herpes simplex virus infections. Infect Immun 39:532-538

3. Kohl S, West MS, Prober CG, Sullender WM, Loo LS, Arvin AN 1989 Neonatal antibody-dependent cellular cytotoxic antibody levels are associated with the clinical presentation of neonatal herpes simplex virus infection. $J$ Infect Dis 160:770-775

4. Brown ZA, Benedetti J, Ashley R, Burchett S, Sellse S, Berry S, Vontuer LA Corey $L 1991$ Neonatal herpes simplex virus infection in relation to asymptomatic maternal infection at the time of labor. N Engl J Med 324:12471252

5. Kohl S, Strynadka NCJ, Hodges RS, Pereira L 1990 Analysis of the role of antibody-dependent cellular cytotoxicity antibody activity in murine neonatal herpes simplex virus infection with antibodies to synthetic peptides of glycoprotein D and monoclonal antibodies to glycoprotein B. J Clin Invest 86:273-278

6. Oakes JE, Rosemond-Hornbead H 1978 Antibody-mediated recovery from subcutaneous herpes simplex virus type 2 infection. Infect Immun 21:489495

7. Georgiades JA, Montgomery J, Hughes TK. Jensen D, Baron S 1982 Determinants of protection by human immune globulin against experimental herpes neonatorum. Proc Soc Exp Biol Med 170:291-297

8. Baron S, Worthington MG, Williams J, Gaines JW 1976 Postexposure serum prophylaxis of neonatal herpes simplex virus infection of mice. Nature 261:505-506

9. Luyet F, Samra D, Soneji A, Marks MI 1975 Passive immunization in experimental herpes virus hominis infection of newborn mice. Infect Immun 12:1258-1261

10. Strulovitch C, Marks MI, Soneji A, Goldberg S 1979 Immunotherapy and drugs in neonatal disseminated herpes simplex virus type 2 infections: a mouse model. J Antimicrob Chemother 5:437-446

11. Kohl S, Loo LS 1984 The relative role of transplacental and milk immune transfer in protection against lethal herpes simplex virus infection in mice. $J$ Infect Dis 149:38-42

12. Hayashi Y, Wada T, Mori R 1983 Protection of newborn mice against herpes simplex virus infection by prenatal and postnatal transmission of antibody. J Gen Virol 64:1007-1012

13. Fallot ME, Boyd JL, Oski FA 1980 Breast-feeding reduces incidence of hospital admissions for infection in infants. Pediatrics 65:1121-1124

14. Frank AL, Taber LH, Glezen WP, Kasel GL, Wells CR, Paredes A 1982 Breast-feeding and respiratory virus infection. Pediatrics 70:239-245

15. Goldman AS, Goldblum RM 1990 Human milk: immunologic-nutritional relationships. Ann NY Acad Sci 587:236-245

16. Michaels R 1965 Studies of antiviral factors in human milk and serum. J Immunol 94:262-271

17. Ogra PL, Fishaut M 1990 Human breast milk. In: Remington JS, Klein JO (eds) Infectious diseases of the fetus and newborn infant. Saunders, Philadelphia, pp 68-88

18. Welsh JK, May JT 1979 Anti-infective properties of breast milk. J Pediatr $94: 1-7$

19. Isaacs CE, Thormar $H$, Pessolano $T 1986$ Membrane-disruptive effect of human milk: inactivation of enveloped viruses. J Infect Dis 154:966-971

20. Thormar H, Isaacs CE, Brown HR, Barshatzky MR. Pessolano T 1987 Inactivation of enveloped viruses and killing of cells by fatty acids and monoglycerides. Antimicrob Agents Chemother 31:27-31

21. Matthews THJ, Lawrence MK. Nair CDG, Tyrrell DAJ 1976 Antiviral activity in milk of possible clinical importance. Lancet 2:1387-1389

22. Lopez I, Quibriac M, PetitJean J, Bazin M, Duhamel JF, Freymuth F 1989 Neutralizing activity against herpes simplex virus in human milk. Arch Fr Pediatr 46:263-265

23. Lawton JWM, Shortridge KF 1977 Protective factors in human breast milk and colostrum. Lancet 1:253

24. Emodi G, Just M 1974 Interferon production by lymphocytes in human milk. Scand J Immunol 3:157-160

25. Kohl S, Pickering LK, Cleary TG, Steinmetz KD, Loo LS 1980 Human colostral cytotoxicity. II. Relative defects in colostral leukocyte cytotoxicity and inhibition of peripheral blood leukocyte cytotoxicity by colostrum. J Infect Dis 142:884-891

26. Glass RI, Svennerholm A, Stoll BJ, Khan MR, Belayet Hossain KM, Imdadul Huq M, Holmgren J 1983 Protection against cholera in breast-fed children by antibodies in breast milk. N Engl J Med 308:1389-1392

27. Cruz JR, Cano F, Caceres P, Pareja G 1988 Breast milk anti-Escherichia col heat-labile toxin IgA antibodies protect against toxin-induced infantile diarrhea. Acta Paediatr Scand 77:658-662

28. Ruiz-Palacios GM, Calva JJ, Pickering LK, Lopez-Vidal Y, Volkow P, Pezzarossi H, West MS 1990 Protection of breast-fed infants against Campylobacter diarrhea by antibodies in human milk. J Pediatr 116:707-713

29. McLean BS, Holmes IH 1981 Effects of antibodies, trypsin, and trypsin inhibitors on susceptibility of neonates to rotavirus infection. J Clin Microbiol 13:22-29

30. Jayashree S, Bhan MK, Kumar R, Bhandari N, Swazawal S 1988 Protection against neonatal rotavirus infection by breast milk antibodies and trypsin inhibitors. J Med Virol 26:333-338

31. Plotkin SA, Katz M, Brown RE, Pagano JS 1966 Oral poliovirus vaccination in newborn African infants. Am J Dis Child 111:27-30

32. Bernstein DI, Garratty E, Lovett MA, Bryson YJ 1985 Comparison of western blot analysis to microneutralization for the detection of type-specific herpes simplex virus antibodies. J Med Virol 15:223-230

33. Goodhart GL, Feorino PM, Shore SL 1980 Herpes simplex virus immune status as determined by different assays. Clin Res 28:369(abstr)

34. Kahlon J, Lakeman FD, Ackermann M, Whitley RJ 1986 Human antibody response to herpes simplex virus-specific polypeptides after primary and recurrent infection. J Clin Microbiol 23:725-730

35. Kohl S, Adam E, Matson DO, Kaufman RH, Dreesman GR 1982 Kinetics of human antibody responses to primary genital herpes simplex virus infection. Intervirology 18:164-168

36. Shore SL, Black CM, Melewicz FM, Wood PW, Nahmias AJ 1976 Antibodydependent cell mediated cytotoxicity to target cells infected with type 1 and type 2 herpes simplex virus. J Immunol 116:194-201

37. Ogra SS, Ogra PL 1978 Immunologic aspects of human colostrum and milk. I. Distribution, characteristics, and concentrations of immunoglobulins at different times after the onset of lactation. J Pediatr 92:546-549

38. Cunningham AS, Jelliffe DB, Jelliffe EFP 1991 Breast-feeding and health in the 1980s: a global epidemiologic review. J Pediatr 118:659-666

39. Svirsky-Gross $S 1958$ Pathogenic strains of $E$. coli among prematures and the use of human milk in controlling the outbreak of diarrhea. Ann Pediatr (Paris) 190:109-115

40. Gunn RA, Kimball AM, Pollard RA, Feeley RC, Felman RA, Dutta SR, Mathew PP, Levine MM 1979 Bottle-feeding is a risk factor for cholera in infants. Lancet 2:730-732

41. Stoll BJ, Glass RI, Hug MI 1980 Epidemiologic and clinical features of patients infected with Shigella who attended a diartheal disease hospital in Bangladesh. J Infect Dis 146:177-183

42. Cochi SL, Fleming DW, Hightower AW, Limpakarnjanarat K, Facklam RR, 
Smith JD, Sikes RK, Broome CV 1986 Primary invasive Haemophilus influenzae type $\mathrm{b}$ disease: a population-based assessment of risk factors. $\mathrm{J}$ Pediatr 108:887-896

43. Istre GR, Conner JS, Broome CV, Hightower A, Hopkins RS 1985 Risk factors for primary Haemophilus influenzae disease: increased risk from day care attendance and school-aged household members. J Pediatr 106:190-195

44. Lum LK, Ward JI, Bender TR 1982 Protective influence of breastfeeding on the risk of developing $H$. influenzae type b disease. Pediatr Res 16:151 A(abstr 436)
45. Takala AK, Eskola J, Palmgren J, Ronnberg P-R, Kela E, Rekola P, Makela PH 1989 Risk factors of invasive Haemophilus influenzae type b disease among children in Finland. J Pediatr 115:694-701

46. Paradise JL, Elster BA 1984 Evidence that breast milk protects against otitis media with effusion in infants with cleft palate. Pediatr Res 18:283A(abstr 1123)

47. Wright AL, Holberg CJ, Martinez FD, Morgan WJ, Taussig LM 1989 Breastfeeding and lower respiratory tract illness in the first year of life. Br Med J [Clin Res] 299:946-949

\section{Announcement}

\section{Charles E. Culpeper Foundation Scholarships in Medical Science}

The Charles E. Culpeper Foundation is currently accepting applications for its 1993 Scholarships in Medical Science Program designed to support the career development of academic physicians.

Up to three awards of $\$ 100,000$ per year for 3 years will be made to United States medical schools on behalf of candidates who are U.S. citizens, who have received their M.D. degree from a U.S. medical school in 1984 or later, and who are judged worthy of support by virtue of the quality of their research proposals. All scientific research relevant to human health is eligible for consideration. No institution may nominate more than one candidate.

In selecting awardees, emphasis will be on identifying young physicians with clear potential for making substantial contributions to science as academic physicians. Since January 1988, 15 physicians have been selected as Charles E. Culpeper Foundation Medical Scholars, three each in the years 1988 through 1992.

Deadline for applications is August 14, 1992. Awards will be announced by January 15, 1993 for activation on or about July 1, 1993. Application forms and instructions may be obtained by contacting the Charles E. Culpeper Foundation at Financial Centre, 695 East Main Street, Suite 404, Stamford, CT 06901. 